\title{
Biochemical Composition of Caprine Follicular Fluid in Relation with Different Follicles Size in Iraqi local goats
}

\author{
Talib Musa Al-Hamedawi, Saded Jaafer Zalzala*, Salah Mahdi AL-Shammary
}

College of Veterinary Medicine, Baghdad University, Baghdad, Iraq.

\begin{abstract}
The study was conducted on 218 caprine ovaries belonging to 109 Iraqi local goats that have been slaughtered in the Al-Shulla and Al-Bayaa regions in Baghdad,Iraq during the period from February 2016 to July 2016. The ovaries collected from 3-5 years old animals were divided into three groups according to the follicles size (small: $<3$ $\mathrm{mm}$, medium: $3-5 \mathrm{~mm}$ and large: $5>\mathrm{mm})$. The results showed significant differences $(\mathrm{p}<0.05)$ in the glucose for the medium follicle $(\mathrm{MF})$ and large follicle $(\mathrm{LF})$ groups as compared with a small follicle group (SF). The total protein of SF group was significantly $(\mathrm{p}<0.05)$ excelled other groups, while cholesterol levels showed the significant differences $(\mathrm{p}<0.05)$ among all groups. The calcium and magnesium concentration in MF and LF groups was significantly $(\mathrm{P}<0.05)$ higher compared to the SF group. On the contrary, the potassium in SM group was significantly $(\mathrm{p}<0.05)$ higher than the concentration in MF and LF groups. The concentration of estrogen and progesterone hormones shown significant differences $(\mathrm{P}<0.05)$ in the $\mathrm{MF}$ and $\mathrm{LF}$ as compared with the SF group, while the differences in the testosterone were not significant among the different groups. In conclusion: the changes in the metabolites concentration (total protein and cholesterol) and ions concentration (calcium and magnesium) as well as hormones concentration (estrogen and progesterone) could be associated with the size of the follicle in goats.
\end{abstract}

Keywords | Estrogen, Progesterone, Follicles size, Iraqi local goats

Editor | Kuldeep Dhama, Indian Veterinary Research Institute, Uttar Pradesh, India.

Received | January 10, 2017; Accepted | February 29, 2017; Published | March 20, 2017

*Correspondence | Sadeq Jaafer Zalzala, College of Veterinary Medicine, Baghdad University, Baghdad, Iraq; E-mail: sadeq.jaffar1@gmail.com

Citation | Al-Hamedawi TM, Zalzala SJ, AL-Shammary SM (2017). Biochemical Composition of Caprine Follicular Fluid in Relation with Different Follicles Size in Iraqi local goats. Adv. Anim. Vet. Sci. 5(3): 145-147.

DOI | http://dx.doi.org/10.14737/journal.aavs/2017/5.3.145.147

ISSN (Online) | 2307-8316; ISSN (Print) | 2309-3331

Copyright $(0) 2017$ Hamedawi et al. This is an open access article distributed under the Creative Commons Attribution License, which permits unrestricted use, distribution, and reproduction in any medium, provided the original work is properly cited.

\section{INTRODUCTION}

$\mathrm{F}$ lliculogenesis is an ordered sequence of development and variation steps including both somatic and germ cells in an ovarian follicle and represented the production of oocyte composition which indicated to fertilization and embryonic development (Glister et al., 2003; Ana and Adrain, 2012; Tripathi et al., 2015). The ovarian follicle size classification in goat as reported by Ahmed-Ali and $\mathrm{Du}^{-}$ bos (1995) is considered the small follicle $(>3 \mathrm{~mm})$, medium follicle $(3-5 \mathrm{~mm})$ and large follicle $(5<\mathrm{mm})$ in diameter. Follicular fluid component has been under intensive investigation in recent times to increase knowledge of follicular maturation and follicular atresia (Singh et al., 1999; Hafez,
1987). The theca cells converted cholesterol into testosterone under LH effect, finally gets changed to estradiol 17.B in granulosa cells under the effect of FSH (Mishra et al., 2003; Deshpande and Pathak, 2010). The biochemical profiles in goat concerning the concentrations of ions $\mathrm{Ca}+$ and $\mathrm{mg}+$ tend to increasing along with the increasing of the follicles size whereas, the potassium concentration decreased with the increasing of the follicles size (Bordoloiet et al., 2001). The concentrations of metabolites (glucose, total protein and cholesterol) may be decrease or increase in different sizes of follicles related with different seasons (Bordoloi et al., 2000; Bordoloi et al., 1999; Maniwa, 2005).The present study aimed to investigate the relationship of ions, metabolites and hormonal concentrations 
with the size of ovarian follicles.

\section{MATERIALS AND METHODS}

The present study was conducted on 218 ovaries (among them were the 109 slaughter Iraqi goats) in Al-Shulla and Al-Bayaa region in Baghdad/Iraq during the period from February 2016 to July 2016 and their age ranged from 3 to 5 years. A total of 218 ovaries were collected with different sizes and divided into three groups; (small: $>3 \mathrm{~mm}$, medium: $3-5 \mathrm{~mm}$, and large: $5<\mathrm{mm}$ ). Ovaries were washed with a chilled normal physiological saline $(0.9 \% \mathrm{NaCl})$ then dried by a filter paper. Aspiration of the follicular fluid was performed by sterilized medical syringes with of $0.25 \times 9.5 \mathrm{~mm}$ and collected the fluid from three different groups. All tubes, which contain fluids, were placed in the centrifuge at $4 \mathrm{C}^{0}$ at $5000 \mathrm{round} /$ minute as was performed by Maniwa et al. (2005). The metabolites (glucose, total protein and cholesterol) analysis was performed using different kits in Spectrophotometer-PD303-Germany. The hormones (estradiol, progesterone and testosterone) were estimated by using ELISA (Metertch-Germany), whereas the analysis of ions was conducted by using the Latrofine kits (Mitsubishi chemical medical group, japan).The data were subjected to the statistical analysis using SPSS. Oneway ANOVA and least significant differences (LSD) post hoc tests were performed to assess significant differences among means where $\mathrm{P}<0.05$ was considered statistically significant.

Table 1: Means $\pm S E$ of the metabolites concentrations of follicular fluid in the Iraqi local goats

\begin{tabular}{llll}
$\begin{array}{l}\text { Metabolites concen- } \\
\text { tration }\end{array}$ & $\mathbf{S F}>\mathbf{3} \mathbf{~ m m}$ & $\begin{array}{l}\text { MF } \\
\mathbf{3 - 5} \mathbf{~ m m}\end{array}$ & $\begin{array}{l}\mathbf{L F} \\
\mathbf{5}<\mathbf{m m}\end{array}$ \\
\hline $\begin{array}{l}\text { Glucose }(\mathrm{mM}) \\
\text { Total proteins }(\mathrm{gm} / \mathrm{dl})\end{array}$ & $2.23 \pm 1.36 \mathrm{~b}$ & $3.78 \pm 0.74$ a & $3.25 \pm 1.76 \mathrm{a}$ \\
\hline $\begin{array}{l}\text { Cholesterol }(\mathrm{mM}) \\
\text { Different letters mean }\end{array}$ & $4.57 \pm 0.43$ a & $3.88 \pm 0.29 \mathrm{~b}$ & $3.14 \pm 0.12 \mathrm{~b}$ \\
\hline
\end{tabular}

\section{RESULTS AND DISCUSSION}

Analysis of different components showed that the mean concentration of MF and LF differed significantly $(\mathrm{p}<0.05)$ as compared with SF (Table 1 ). These results demonstrated that glucose concentration increase as follicle size increase. The glucose play important role in the metabolism of ovarian because it considered the financier main energy for the ovary. The high concentration of glucose could be attributed to that the breakdown of glucose could be less intensive in large follicles compared with small follicles. These results are in agreement with Thakur et al. (2003) and Nandi et al. (2007). In regards with, the total protein results showed that $\mathrm{SF}$ group significantly $(\mathrm{P}<0.05)$ excelled each of MF and LF. Similar results were obtained by Mishra et al. (2003). The concentrate of the cholesterol showed the same trend of glucose as it increased significantly $(\mathrm{P}<0.05)$ along with the increasing of the follicles. The cholesterol considered as the precursor of steroid hormones (estrogen and progesterone). These results are in consistence with results reported by Nandi et al., (2007).

Results showed that calcium and magnesium concentration in MF and LF are significantly $(\mathrm{P}<0.05)$ excelled the SF (Table 2). These results agreed with some studies obtained by Bordoloi et al. (2001) and Thakur et al. (2003). The increasing of calcium concentration with follicular development has a role in the steroidogenic capability of growing follicle besides its role in the gonadotrophin regulation of ovarian steroidogenosis and ovulation (Nandi et al., 2007). On the other hand, the potassium in SF was significantly $(\mathrm{P}<0.05)$ excelled MF and LF. The decreasing of potassium concentration with follicular development could be due to the increase using of glucose by developing follicles this process leads to transfer of potassium from extracellular to intracellular sites (Chang et al., 1976).

Table 2: Means $\pm \mathrm{SE}$ of the ions concentration of follicular fluid in the Iraqi local goats

\begin{tabular}{|llll|}
\hline Ions concentration & $\mathbf{S F}>\mathbf{3} \mathbf{~ m m}$ & MF $3-\mathbf{5 m m}$ & $\mathbf{L F} \mathbf{5}<\mathbf{m m}$ \\
\hline Calcium $(\mathrm{mM})$ & $2.61 \pm 0.36 \mathrm{~b}$ & $3.84 \pm 0.24 \mathrm{a}$ & $3.93 \pm 0.43 \mathrm{a}$ \\
Potassium $(\mathrm{mM})$ & $12.53 \pm 0.16 \mathrm{a}$ & $9.42 \pm 0.13 \mathrm{~b}$ & $8.01 \pm 0.23 \mathrm{~b}$ \\
Magnesium $(\mathrm{mM})$ & $1.14 \pm 0.20 \mathrm{~b}$ & $2.10 \pm 0.18 \mathrm{a}$ & $2.19 \pm 0.03 \mathrm{a}$ \\
\hline Different letters mean significant differences $(\mathrm{P}<0.05)$
\end{tabular}

Table 3: Means $\pm \mathrm{SE}$ of the hormones concentration of follicular fluid in the Iraqi local goats.

\begin{tabular}{llll}
$\begin{array}{lll}\text { Hormones concen- } \\
\text { tration }\end{array}$ & $\begin{array}{l}\text { SF } \\
\mathbf{3} \mathbf{m m}\end{array}$ & $\begin{array}{l}\text { MF } \\
\mathbf{3 - 5} \mathbf{m m}\end{array}$ & $\begin{array}{l}\text { LF } \\
\mathbf{5}<\mathbf{m m}\end{array}$ \\
\hline Estradiol $\mathrm{ng} / \mathrm{ml}$ & $126.4 \pm 10.32 \mathrm{c}$ & $156.6 \pm 8.34 \mathrm{~b}$ & $169.3 \pm 11.12 \mathrm{a}$ \\
Progesterone $\mathrm{pg} / \mathrm{ml}$ & $214.2 \pm 16.43 \mathrm{c}$ & $261.5 \pm 14.87 \mathrm{~b}$ & $322.5 \pm 32.56 \mathrm{a}$ \\
Testosterone $\mathrm{pg} / \mathrm{ml}$ & $193.6 \pm 5.36 \mathrm{a}$ & $195.2 \pm 11.24 \mathrm{a}$ & $198.7 \pm 8.24 \mathrm{a}$ \\
Different letters mean significant differences $(\mathrm{P}<0.05)$
\end{tabular}

The results also revealed that the concentration of the estrogen and progesterone hormones record significant difference $(\mathrm{P}<0.05)$ in the MF and LF as compared with SM (Table 3). The concentration of estradiol in follicular fluid was recorded $126.4 \pm 10.32 \mathrm{ng} / \mathrm{ml}, 156.6 \pm 8.34 \mathrm{ng} / \mathrm{ml}$ and $169.3 \pm 11.12 \mathrm{ng} / \mathrm{ml}$ in SF, MF and LF respectively. In recent study of silent estrus results demonstrated smaller size and slower growth rate of the dominant ovulatory follicle associated with lesser concentration of estradiol (Pang et al., 2010). The concentration of progesterone was recorded $214.2 \pm 16.43 \mathrm{pg} / \mathrm{ml}, 261.5 \pm 14.87 \mathrm{pg} / \mathrm{ml}$ and $322.5 \pm 32.56 \mathrm{pg} / \mathrm{ml}$ in SF, MF and LF respectively. The progesterone plays a key role in the regulation of the oestrous cycle. These results agreed with Moradi and Kolsum (2013) while testosterone did not record a significant dif- 
OPEN OACCESS

ference between the different groups. Similar results were obtained by Kim et al. (2001).

\section{CONCLUSION}

Changes in the metabolites concentration (total protein and cholesterol) and ions concentration (calcium and magnesium) as well as hormones concentration (estrogen and progesterone) could be associated with the size of the follicle in Iraqi goats.

\section{CONFLICT OF INTEREST}

The authors declare that there is no conflict of interest regarding the publication of this research paper.

\section{AUTHORS' CONTRIBUTIONS}

All authors contributed equally.

\section{REFERENCES}

-Ahmed-Ali MN, Dubos MP (1995). Development competence of goat oocytes from follicles of different size categories following maturation, fertilization and culture in vitro. J. Reprod. Fertil. 103: 293-298. https://doi.org/10.1530/ jrf.0.1030293

-Ana M, Rosales-Torres, Adrian GA (2012).Follicular development in domestic ruminants. Trop. Subtrop. Agroecosysts. 15: 147-160.

- Bordoloi PK, Sarmah BC, Dutta DJ, Deka BC (1999). Acid and alkaline phosphatase activity in follicular fluid of goat ovary. Indian J. Anim. Res. 33: 144-146.

- Bordoloi PK, Sarmah BC, Dutta DJ, Deka BC (2000). Follicular fluid cholesterol in goat ovary. Indian Vet. J. 77: 638-639.

-Bordoloi PK, Sarmah BC, Dutta DJ, Deka BC (2001). Macro and micro minerals in Caprine follicular fluid. Indian J. Anim. Reprod. 22: 23-25.

- Chang SCS, Jones JD, Ellefson AD and Ryan AJ (1976). The porcine ovarianfollicle: selected chemical analysis of follicular fluid at different developmental stages. Biol. Reprod. 15: 321-328. https://doi.org/10.1095/biolreprod15.3.321

- Deshpande SB, Pathak MM (2010). Hormonal and biochemical profiles in follicular fluid of unovulated follicles in super
Advances in Animal and Veterinary Sciences

ovulated goats ovaries. Vet. World. 3(5): 221-223.

- Glister C, Groome NP, Knight PG (2003). Oocyte-mediated suppression of follicle stimulating hormone and insulin like growth factor induced secretion of steroids and inhibin related proteins by bovine granulosa cells in vitro: possible role of transforming growth factor- $\alpha$. Biol. Rep. 68: 758765. https://doi.org/10.1095/biolreprod.102.008698

- Hafez ESE (1987). Reproduction in Farm Animals $5^{\text {th }}$ edition. K.M. Varghese Company Post Box 7119 show Bombay, India.

- Kim JY, Kinoshita M, Ohnishi M, Fukui Y (2001). Lipid and fatty acid analysis of fresh and frozen-thawed immature and in vitro matured bovine oocytes. Reprod. 122(1): 131-138. https://doi.org/10.1530/rep.0.1220131

- Maniwa J, Izumi S, Isobe N, Terada T (2005). Studies on substantially increased proteins in follicular fluid of bovine ovarian follicular cysts using 2-D PAGE and MALDI-TOF MS. Rep. Biol. End. 3 (23).

- Mishra OP, Pandey JN, Gawande PG (2003). Study on biochemical constituents of Caprine ovarian follicular fluid after superovulation. Asian Aust. J. Anim. Sci. 16: 17111715. https://doi.org/10.5713/ajas.2003.1711

- Moradi NK, Kolsum M (2013). A review of biochemicalmetabolites concentration and hormonal composition of ovarian follicular fluid in domestic animals. Ann. Rev. Res. Biol. 3(3): 246-255.

- Nandi S, Kumar VG, Manjunatha BM, Gupta PSP (2007). Biochemical composition of ovine follicular fluid in relation to follicle size. Develop. Growth Differ. 49: 61-66. https:// doi.org/10.1111/j.1440-169X.2007.00901.x

- Pang XS, Wang ZY, Zhu TG, Yin DZ, Zhang YL, Meng L, Wang F (2010). Concentrations of progesterone and estradiol in peripheral plasma during the estrous cycle and after ovariectomy in Huanghuai goats of high or poor prolificacy. Asian-australians J. Anm. Sci. 23:188-196.

- Singh D, Sharma MK, Pandey RS (1999). Biochemical and hormonal characterization of follicles from follicular and luteal phase ovaries of goat and sheep. Indian J. Exp. Biol. 37: 434-438.

-SPSS (2008). Statical Package for Social Science, SPSS users Guide Statistics Version 16, NC, USA.

- Tripathi S, Farman M, Nandi S, Girish Kumar V, Gupta PSP (2015). Biochemical constituents of ovarian follicular fluid in ruminants and their significance in follicle and oocyte development. Vet. Sci. Med. Diagn. 4: 3.

- Thakur RS, Chauhan RAS, Singh BK (2003). Studies on biochemical constituentsof caprine follicular fluid. Indian Vet. J. 80: 160-162. 